\title{
Incidence of Child Labour and Child Schooling in India: Pattern and Determinants
}

\author{
Saswati Das \\ Economic Research Unit, Indian Statistical Institute, 203 B. T. Road, Kolkata 700 108, India \\ Correspondence should be addressed to Saswati Das, saswatid@isical.ac.in \\ Received 20 April 2012; Accepted 19 June 2012 \\ Academic Editors: M. Tsionas and R. Wright
}

Copyright () 2012 Saswati Das. This is an open access article distributed under the Creative Commons Attribution License, which permits unrestricted use, distribution, and reproduction in any medium, provided the original work is properly cited.

The issue of child labour is a frontline concern in India, as early entry into labour market at formative stage of life does mean absconding from proper schooling leading to loss of future scope of better livelihood, since the existing literature shows that there is wage premium for education in Indian labour market. In this perspective, this study aims to carry out a supply-side analysis towards examining the incidence and pattern of child labour and child schooling to test out regional and gender disparities, if any, in terms of these incidences. Socio-economic determinants across gender and region also have been identified for an everlasting way out of the crisis. The data-base utilized for the analysis has been extracted from the National Sample Survey on "Employment and Unemployment Situation in India" for the 61st large sample round (2004-2005). The pattern of child employment in a range of industries confirms the malfunctioning of lawful steps to save child labourers from mischief of occupational vulnerability. It also reveals significant discrepancy in incidence of child labour both across region and gender, but for schooling choice no considerable regional gap is substantiated.

\section{Introduction}

The issue of child labour is closely related with human capital formation of a country as early entry in labour market leads to the refutation of normal childhood and absconding from proper schooling, implying a loss in future scope of better earning. Global estimates of the International Labour Organisation (ILO) show that the incidence of child labour is very high in developing countries and statistics reveal that India is the highest in the world. So there is no doubt that in India the issue of child labour is a serious one. Although there is a universal agreement that child labour is undesirable, there is a wide disagreement on how to tackle this problem. The formulation of policies that are effective in curbing child labour requires an analysis of its key determinants, that is, identification of variables that have a significant effect on child employment. The rapidly expanding literature on child labour has focused attention not only on the qualitative features of child labour but also on the quantitative aspects taking advantage of the increasing availability of good quality data on child employment. The empirical literature on child labour has been shifted from mere quantification to an econometric analysis of its determinants. Mention may be made of studies done by Psacharopoulos [1] on Venezuela, Jensen and Nielsen [2] on Zambia, Ray [3] on Pakistan and Peru, Ravallion and Wodon [4] on Bangladesh, Das and Mukherjee [5], and Mukherjee and Das [6] on India. These studies demonstrate several factors contributing to the decision to send a child to work.

In this context, the objective of the proposed study is to examine the problem from supply side for suggesting some different kinds of policy prescriptions such that the parents themselves will withdraw their children from the labour market and then the market will eventually experience an equalization of wages for adult and child labour making a permanent solution to this problem. Child labour, so long a cheaper substitute of adult labour, would have its demand in the market for unskilled work, and so trying to solve the problem from demand side needs legal interventions. Studies show that though there are some laws to protect child labour, there is also evasion of those laws. Moreover, as children are less demanding, more obedient, and require lower pay, so it is very likely that demand for child labour will persist in some sectors. Studies made by Trade Environment Development 
[7] find that in many cases there are government officials who personally benefit from child labour. Moreover, the upper caste people do not see anything wrong with using children of lower castes and classes as labour. The study shows that 80 percent of the working children in India are the children of the Dalits, who are oppressed low caste or minority tribal people. The study made by Swaminathan [8] in western India reveals that children work at simple repetitive manual tasks that do not require long years of training or experience in low-paying hazardous works that involves drudgery and forecloses the option of school education for most children.

In developing countries, it is widely believed that poverty plays as a determining force for many children to work full time for their own and their families' survival. This can be judged testing the "luxury axiom" introduced by Basu and Van [9]: "a family will send the children to the labour market only if the family's income from non-childlabour sources drops very low." An empirical evaluation of this hypothesis may throw light on the important question of whether poverty is the key determinant of child labour. (Using data from Peru and Pakistan, Ray [3] tested two hypotheses that there is a positive association between hours of child labour and poverty and that there is a negative association between child schooling and poverty. Both of these hypotheses were confirmed by the Pakistani data, but not by the Peruvian data.) Even though poverty is likely to be a major driving force towards child labour decision, there are some other potential factors influencing this decision. The study made by Das and Mukherjee [5] addressed two broad issues in urban Indian context, namely, return to investment in education in job market; linkage between parental human capital and children outcomes in the household in terms of extent of schooling, tendency to drop out, and decision to work as child labour. The study shows that there exists significant wage premium in Indian labour market. Major finding of this study establishes the linkage of parental education with child schooling and child work decisions in the family for urban boys. Similar findings were obtained in the study of Mukherjee and Das [6] for urban boys and girls too. This is likely not only for economic reason but also because parents may have some noneconomic, that is, purely social inclination towards educating their children and this propensity would be contingent on the level of parental education.

In earlier works of Das and Mukherjee [5], and Mukherjee and Das [6], the issue of child labour was addressed only for urban Indian children. In these works, addressing the issue for rural Indian children was untouched. But considering the wide regional variation in labour market characteristics as well as household characteristics, along with the reality, the issue is largely rural phenomena (as large section of child labourers are from rural India), it is essential to work out for children from rural area. It is also needed to address the gender differentials in terms of pattern and incidence of labour type of activities of Indian children. As decisions regarding work and schooling are simultaneous and interdependent, it necessitates addressing child schooling as well. It may be noted that when we are discussing about intrahousehold decisions on child schooling, we are basically talking about the demand for child education within the household. Discontinuation (dropout) of schooling can be considered as a key indicator of demand for child education within the household. In this context, here, the present work is to address the following broad issues:

(i) to identify the key industries of child employment by region (rural/urban) and sex (male child/female child);

(ii) to identify supply side variables of household decision of sending a child to work by region and sex;

(iii) to identify demand side variables of household decision of child schooling in terms of decision of dropout, by region and sex;

(iv) to check regional and gender disparities in terms of these decisions.

The rest of the paper is organized as follows. Section 2 discusses the data and methodological issues. Section 3 is presenting incidence of child labour in India. Section 4 explores the determinants of child labour and child schooling in India. Lastly, Section 5 concludes.

\section{Data and Methodology}

2.1. The Sample. Unit level data of National Sample Survey (NSS) for 61st round (2004-2005) on employment and unemployment have been used in the present study. The salient feature of this survey is that the survey period is divided into four sub-rounds, each with duration of three months to capture the seasonal effect on employment opportunity. An equal number of sample villages/blocks are allotted for the survey in each of these four subrounds. At the all-India level, a total number of 8128 villages and 4660 urban blocks are allocated for the survey. The ultimate stage units are households at the subsequent stage. The number of households surveyed was 79,306 in rural areas and 45,374 in urban areas.

2.2. Concepts and Definitions. Let us discuss some concepts and definitions used here.

2.2.1. Household Size. According to NSS (NSSO, [10]) the number of normally resident members of a household is its size. It will include temporary stay-away but exclude temporary visitors and guests. In deciding the composition of a household, more emphasis is placed on "normally living together" than on "ordinarily taking food from a common kitchen.”

2.2.2. Average Monthly Per Capita Expenditure (MPCE). Household income is highly related to employment characteristics and underlying earnings of the household members. As it is difficult to collect reliable income data, the NSSO collects data on consumption expenditure in its surveys and works out monthly per capita consumer expenditure for each sample household, which is expected to serve as a close proxy for income. 
2.2.3. Child Labour. In the ILO guidelines, work is defined in terms of economic activity in the sense of the System of National Accounts (SNA) for measuring GDP. Briefly, economic activity covers all market production (paid work) and certain types of nonmarket production (unpaid work), including production of goods for own use. Therefore, whether paid or unpaid, the activity or occupation could be in the formal or informal sector and in urban or rural areas (ILO, [11]). But work of a domestic nature (household chores) performed by children in their own households is noneconomic activities and thus outside the "production boundary" as defined by the SNA. The minimum age of employment is taken as 15 years, and work between 2-6 hours per day or 14-42 hours/week, which is not hazardous in nature, is defined as regular work for 10-14 years age group. Children in 5-9 years age group, engaged in any economic activity, are defined as child labourers. Hazardous activity is defined as any activity or occupation, which by its nature or type has, or leads to, adverse effects on the child's safety, health (physical or mental), and moral development (ILO, [11]). NSS does not provide hourly data and classify work status depending upon the major time criterion. It defines usual principal activity status of a person as one on which a person spent relatively longer time during the 365 days preceding the date of survey. In this study, only those children have been considered as child labourers those are doing economic activities in usual principal activity status.

2.2.4. Dropout. Dropout child has been defined as who ever attended but discontinued studies to supplement household income or any other reason.

2.3. Model Specification. Based on the discussion made above probit model has been estimated separately for child labour and drop out decisions. As these decisions are not observable (latent variables), so two observable dummies have been defined as following:

$$
\begin{aligned}
& Y_{1}=1 \text { in case of occurrence of incidence } \\
& \text { ofchild labor; } 0 \text { otherwise } \\
& Y_{2}=1 \text { in case of occurrence of incidence } \\
& \text { of drop out; } 0 \text { otherwise. }
\end{aligned}
$$

The regression equation to be estimated, then, is specified as

$$
\begin{aligned}
P\left(Y_{i}=1\right)= & \alpha+\beta_{1} \mathrm{HH}+\beta_{2} \mathrm{MPCE}+\gamma_{1} C_{1}+\gamma_{2} C_{2}+\gamma_{3} C_{3} \\
& +\gamma_{4} R+\delta_{1} \mathrm{Fedu}_{1}+\delta_{2} \mathrm{Fedu}_{2} \\
& +\delta_{3} \mathrm{Medu}_{1}+\delta_{4} \mathrm{Medu}_{2}+\varepsilon
\end{aligned}
$$

where $\mathrm{HH}=$ household size; $\mathrm{MPCE}=$ average monthly per capita expenditure; $C_{1}=$ indicator or dummy variable for scheduled tribe; $C_{2}=$ indicator or dummy variable for scheduled caste; $C_{3}=$ indicator or dummy variable for other backward caste; $R$ = indicator or dummy variable for "religion $=$ Hindu"; Fedu ${ }_{1}=$ indicator or dummy variable for father's education, "up to middle"; $\mathrm{Fedu}_{2}=$ indicator or dummy variable for father's education, "above middle;" $\mathrm{Medu}_{1}=$ indicator or dummy variable for mother's education, "up to middle;" $\mathrm{Medu}_{2}=$ indicator or dummy variable for mother's education, "above middle." $\alpha, \beta^{\prime} s, \gamma^{\prime} s, \delta^{\prime} s$ are the parameters of the model, and $\varepsilon$ is the random noise term. The regression equation has been estimated separately for each region and each sex.

To check the effect of (i) difference in region; and (ii) difference in gender, on decisions of child employment and dropout two qualitative variables have been included in the form of two dummy variables as follows:

$$
\begin{aligned}
& D_{\text {reg }}=1 \text { if the observation is from rural and } 0 \\
& \text { otherwise; } \\
& D_{\text {sex }}=1 \text { if the child is female and } 0 \text { otherwise. }
\end{aligned}
$$

Data set has been pooled accordingly, to estimate following equation, separately, for incidence of child labour and dropout:

$$
\begin{aligned}
P\left(Y_{i}=1\right)= & \alpha+\beta_{1} \mathrm{HH}+\beta_{2} \mathrm{MPCE}+\gamma_{1} C_{1}+\gamma_{2} C_{2}+\gamma_{3} C_{3} \\
& +\gamma_{4} R+\delta_{1} \mathrm{Fedu}_{1}+\delta_{2} \mathrm{Fedu}_{2}+\delta_{3} \mathrm{Medu}_{1} \\
& +\delta_{4} \mathrm{Medu}_{2}+\gamma_{5} D_{\mathrm{reg}}+\gamma_{6} D_{\text {sex }}+\varepsilon .
\end{aligned}
$$

Here, the testing hypotheses are as stated in the following:

$\mathrm{H}_{1 \mathrm{~A}}$ : there is no regional difference in terms of incidence of child labour and dropout (i.e., $\gamma_{5}=0$ ).

$\mathrm{H}_{1 \mathrm{~B}}$ : there is no gender difference in terms of incidence of child labour and dropout (i.e., $\gamma_{6}=0$ ).

The test results are discussed in Section 4.

\section{Incidence of Child Labour in India}

Child labour does mean absconding from proper schooling. It is evidenced from Table 1. It is distinctly clear from Table 1 that the dropout phenomenon sharply increases with level of education. This is surprising because the incentive for staying in school for a substantial number of years is quite strong in Indian labour market (Das and Mukherjee, [5]). The education premium is present in the child labour market too, in a weaker sense. It can also be noted that incidence of dropout is more pronounced among urban children between primary and middle levels of education. It is possible due to diverse job opportunities in urban labour market, pulling more children to job market at the cost of education.

Table 2 depicts the rates of incidence of child labour in India across region and sex for two common age groups, 59 years and 10-14 years separately. The incidence rates are uniformly lower for the younger cohort than the older one. The range of values for $\mathrm{I}(L)$ varies from 0.1 percent to 5.4 per cent. It can be noted that the girl children are less involved in wage economic activity, and hence they show up less in the labour $(L)$ status. Consequently, incidence of child labour is higher for boys. Incidence of child labour in rural area is 
TABLE 1: Level of education among child labourers in India by region and sex, 2004-2005.

\begin{tabular}{lcccc}
\hline Level of education & Rural & & Urban & Male (\%) \\
\hline Not literate & Male (\%) & Female (\%) & 58.13 & 47.46 \\
Literate but below primary & 44.87 & 15.01 & 23.26 & 17.51 \\
Primary & 19.28 & 23.23 & 23.26 & 29.94 \\
Middle & 27.28 & 8.80 & 5.08 & 4.52 \\
Above middle & 8.00 & 0.72 & 0.00 & 0.00 \\
\hline Total & 0.57 & 100 & 100 & 100 \\
\hline
\end{tabular}

TABLE 2: Incidence of child labour in India by region and sex, 2004-05.

\begin{tabular}{|c|c|c|c|c|c|}
\hline Region & Gender & Age group & $\begin{array}{l}\text { Total number of } \\
\text { sample children in } \\
\text { NSS }=N_{\mathrm{ch}}\end{array}$ & $\begin{array}{c}\text { Number of child } \\
\text { labour in sample }=L\end{array}$ & $\begin{array}{l}\text { Incidence of child labour, } \\
\quad I(L)=\left(L / N_{\mathrm{ch}}\right) * 100\end{array}$ \\
\hline \multirow{4}{*}{ Rural } & \multirow{2}{*}{ Male } & $5-9$ & 24315 & 49 & 0.2 \\
\hline & & $10-14$ & 24981 & 1349 & 5.4 \\
\hline & \multirow{2}{*}{ Female } & $5-9$ & 21899 & 25 & 0.1 \\
\hline & & $10-14$ & 21882 & 1072 & 4.9 \\
\hline \multirow{4}{*}{ Urban } & \multirow{2}{*}{ Male } & $5-9$ & 10835 & 22 & 0.2 \\
\hline & & $10-14$ & 11770 & 518 & 4.4 \\
\hline & \multirow{2}{*}{ Female } & $5-9$ & 9817 & 11 & 0.1 \\
\hline & & $10-14$ & 10796 & 259 & 2.4 \\
\hline
\end{tabular}

much higher than that of urban area. This prompts to test if there are significant regional and gender differences affecting schooling and child labour decisions. Testing hypotheses have been formulated accordingly, as described in Section 2.

The pattern of child employment in various industries is well evident from Table 3. It clearly shows the sectors, those are engaging the children in labour market at too early age. A large number of children are engaged in agriculture, forestry, and fishing in rural sector, while in urban, manufacturing and trade are two major sectors of child employment. In the rural, children are also working in a significant percentage in manufacturing of tobacco products; spinning, weaving, and finishing of textiles; nonspecialized retail trading stores, and so forth. Very few of them are also engaged in mining and quarrying sector. On the other hand, in urban, they are engaged largely in enterprises, like manufacturing of tobacco products, manufacturing of textiles, retail trade, hotels, and restaurants. More precisely, boys are employed in manufacturing of food products and beverages, manufacturing of wearing apparel, dressing and dying of fur, tanning and dressing of leather goods, manufacturing of textiles, and so forth. A moderately high percentage (about 11 per cent) is working in hotels and restaurants. Girls are employed in manufacturing of carpet and rugs other than by hand as well as blankets, shawls, embroidery work, and making of ornamental trimmings by hand. A part of girl child labourers are engaged in activities of private households as domestic staff like maids, cooks, waiter, and so forth (This is included in "others" category.) It indicates a varying pattern in child employment across sex and region implying the need of gender and region specific policy intervention for proper eradication of the problem.

According to Government of India, there are 2 million children working in hazardous industries (UNICEF [12]). Child Labour Act in 1986 outlaws child labour in hazardous occupations. But after twenty-five years of enactment of this act, about 10 per cent of male child labourers in rural sector and 21 per cent in urban sector are still occupied in hazardous occupations. The identification of hazardous work was due to the list of state prohibited occupations prepared by the New York State Department of Labour [13]. Effort was to make an exact matching of these listed occupations with those of 5-digit National Industrial Classifications in 2004 [14], prepared by the Central Statistical Organization of India. In few cases, some subjective decisions were inevitable. (The list of hazardous industries is provided in the appendix.)

Although there are laws to protect child labourers, still children are employed in hazardous industries, both in rural and urban areas. Not only boys are employed in these occupations, but even girls are employed too. In rural, children are occupied in hazardous industries, like manufacturing of nonmetallic mineral products, manufacturing of fabricated metal products, building of complete constructions or parts thereof, and nonscheduled passengerland-transport like man or animal drawn vehicles. (Girl child labourers (about 5 per cent) are also found to be engaged in nonmetallic mineral products, building of complete constructions, and in domestic duties in other than own houses.) In urban, other than these industries the male 
TAble 3: Percentage distribution of child labour by National Industrial Classification (NIC), 2004-05*.

\begin{tabular}{|c|c|c|c|c|}
\hline Industry & Rural male & Rural female & Urban male & Urban female \\
\hline Agriculture, hunting, and forestry; fishing & 70.48 & 75.57 & 10.22 & 10.11 \\
\hline Manufacturing & 10.64 & 17.57 & 29.24 & 55.32 \\
\hline Construction & 3.78 & 1.29 & 6.60 & 4.26 \\
\hline Retail trade, repair of motor vehicles, and so forth & 7.21 & 1.29 & 33.00 & 8.5 \\
\hline Hotels and restaurants & 2.40 & 0.57 & 11.35 & 1.6 \\
\hline Others & 5.5 & 3.71 & 9.59 & 20.21 \\
\hline Total & 100.01 & 100.00 & 100.00 & 100.00 \\
\hline
\end{tabular}

${ }^{*}$ Industrial categories are merged according to cluster of child labourers in different industries.

TABLE 4: Determinants of incidence of child labour, separate analysis.

\begin{tabular}{|c|c|c|c|c|c|c|c|c|}
\hline \multirow{2}{*}{ Variable } & \multicolumn{2}{|c|}{ Rural boys } & \multicolumn{2}{|c|}{ Rural girls } & \multicolumn{2}{|c|}{ Urban boys } & \multicolumn{2}{|c|}{ Urban girls } \\
\hline & Coefficient & $z$-statistic & Coefficient & $z$-statistic & Coefficient & $z$-statistic & Coefficient & $z$-statistic \\
\hline $\mathrm{HH}$ & -0.09 & $-16.33^{*}$ & -0.11 & $-17.39^{*}$ & -0.05 & $-5.32 *$ & -0.10 & $-8.15^{*}$ \\
\hline MPCE & 0.00 & $-20.13^{*}$ & 0.00 & $-14.63^{*}$ & 0.00 & $-15.53^{*}$ & 0.00 & $-12.28^{*}$ \\
\hline$C_{1}$ & -0.19 & $-4.54^{*}$ & 0.00 & 0.01 & -0.39 & $-3.38^{*}$ & 0.08 & 0.70 \\
\hline$C_{2}$ & -0.38 & $-8.77^{*}$ & -0.53 & $-10.04^{*}$ & -0.33 & $-4.52^{*}$ & -0.36 & $-3.67^{*}$ \\
\hline$C_{3}$ & -0.38 & $-10.17^{*}$ & -0.28 & $-6.36^{*}$ & -0.25 & $-4.52^{*}$ & -0.16 & $-2.18^{*}$ \\
\hline $\mathrm{R}$ & 0.03 & 0.85 & -0.25 & $-5.55^{*}$ & 0.21 & $3.64^{*}$ & 0.13 & 1.82 \\
\hline $\mathrm{FEDU}_{1}$ & -0.47 & $-13.89^{*}$ & -0.46 & $-12.22^{*}$ & -0.48 & $-8.87^{*}$ & -0.32 & $-4.63^{*}$ \\
\hline $\mathrm{FEDU}_{2}$ & -0.82 & $-10.75^{*}$ & -0.84 & $-9.84^{*}$ & -0.88 & $-7.70^{*}$ & -0.63 & $-4.46^{*}$ \\
\hline $\mathrm{MEDU}_{1}$ & -0.43 & $-9.58^{*}$ & -0.55 & $-10.91^{*}$ & -0.43 & $-6.82^{*}$ & -0.46 & $-5.78^{*}$ \\
\hline $\mathrm{MEDU}_{2}$ & -0.55 & $-3.92^{*}$ & -4.00 & -0.04 & -0.97 & $-4.19^{*}$ & -0.97 & $-3.26^{*}$ \\
\hline Number of obsn. & 36328 & - & 30093 & - & 17007 & - & 15140 & - \\
\hline Sum squared residuals & 863.91 & - & 669.44 & - & 349.90 & - & 173.97 & - \\
\hline Log likelihood & -3959.37 & - & -3088.39 & - & -1483.43 & - & -869.77 & - \\
\hline
\end{tabular}

* Significant at $1 \%$.

child labourers are occupied in hazardous occupations like slaughtering, bakery, production of wood, cork, straw, and plaiting materials, glass, and glass products, repairing of motor vehicles, cooking services in restaurants, bars and canteens, and so forth. In urban area (about 8 per cent) girl child labourers are found to be occupied in bakery, manufacturing of nonmetallic mineral products, building of complete construction and doing domestic duties as maids. Gender differentials in child employment do increase both with age and dangers, children face in the workplace. Boys are more involved than are girls in hazardous work. The continuation of child employment in hazardous occupation indicates serious failure of government policy measures in dealing with the issue in India, with the authorities not carrying out comprehensive inspections on establishments employing children in these occupations.

\section{Determinants of Child Labour and Child Schooling}

Regression outputs are presented in Tables 4, 5, and 6 . The first thing to be noted is that the nature of association between socioeconomic variables and dropout or child labour incidence is by and large very similar. It has significant implications in terms of policy measures that improvement in school accessibility would automatically decrease incidence of child labour. Secondly, on the whole, most of the socioeconomic-cultural variables are strongly associated with child schooling, and child labour decisions. In most of the cases, the effect of these variables are significant at 1 per cent.

Regression output for separate analysis (Tables 4 and 5) shows that MPCE and household size, as expected, has a strong impact on both the decisions. In addition to a strong link between MPCE and these decisions, it is encouraging to note that the education variables also have influence on these decisions. As NSS does not provide number of years of education, parental education has been classified into three categories. Taking not literate as reference category, two dummies, one for up to middle and another for above middle have been estimated. A strong incremental impact of level of education can be noted in all cases. Only for rural girl children, dummy for above middle is not significant. This is due to higher level of adult male education compared to that of adult female education. Contrary to our expectation, father's occupation had no significant positive or negative coefficient in the regression results for both the regions and sex. Hence, it was dropped out from the regression equations.

Taking general caste as reference category, three caste dummies (scheduled tribe, scheduled caste, and backward caste) have been estimated. The caste and religion dummies 
TABLE 5: Determinants of incidence of drop out, separate analysis.

\begin{tabular}{|c|c|c|c|c|c|c|c|c|}
\hline \multirow{2}{*}{ Variable } & \multicolumn{2}{|c|}{ Rural boys } & \multicolumn{2}{|c|}{ Rural girls } & \multicolumn{2}{|c|}{ Urban boys } & \multicolumn{2}{|c|}{ Urban girls } \\
\hline & Coefficient & $z$-statistic & Coefficient & $z$-statistic & Coefficient & $z$-statistic & Coefficient & $z$-statistic \\
\hline $\mathrm{HH}$ & -0.14 & $-21.46^{*}$ & -0.16 & $-20.74^{*}$ & -0.11 & $-10.76^{*}$ & -0.12 & $-8.32^{*}$ \\
\hline MPCE & 0.00 & $-15.80^{*}$ & 0.00 & $-12.17^{*}$ & 0.00 & $-13.85^{*}$ & 0.00 & $-11.26^{*}$ \\
\hline$C_{1}$ & -0.25 & $-5.23^{*}$ & -0.24 & $-4.26^{*}$ & -0.43 & $-3.34^{*}$ & -0.08 & -0.58 \\
\hline$C_{2}$ & -0.42 & $-8.65^{*}$ & -0.57 & $-9.64^{*}$ & -0.26 & $-3.36^{*}$ & -0.43 & $-3.81^{*}$ \\
\hline$C_{3}$ & -0.44 & $-10.72^{*}$ & -0.33 & $-7.07^{*}$ & -0.22 & $-3.71^{*}$ & -0.15 & -1.94 \\
\hline $\mathrm{R}$ & 0.05 & 1.21 & -0.22 & $-4.37^{*}$ & 0.18 & $3.02 *$ & 0.01 & 0.16 \\
\hline $\mathrm{FEDU}_{1}$ & -0.36 & $-9.77^{*}$ & -0.30 & $-7.01^{*}$ & -0.35 & $-5.93^{*}$ & -0.23 & $-2.99 *$ \\
\hline $\mathrm{FEDU}_{2}$ & -0.70 & $-8.73^{*}$ & -0.67 & $-7.59^{*}$ & -0.60 & $-5.87^{*}$ & -0.68 & $-4.15^{*}$ \\
\hline $\mathrm{MEDU}_{1}$ & -0.33 & $-7.14^{*}$ & -0.41 & $-7.93^{*}$ & -0.22 & $-3.57^{*}$ & -0.37 & $-4.31^{*}$ \\
\hline $\mathrm{MEDU}_{2}$ & -0.70 & $-4.23^{*}$ & -0.63 & $-4.06^{*}$ & -0.46 & $-3.24^{*}$ & -0.46 & $-2.21^{*}$ \\
\hline Number of obsn. & 36328 & - & 30093 & - & 17007 & - & 15140 & - \\
\hline Sum squared residuals & 614.23 & - & 427.42 & - & 255.36 & - & 122.11 & - \\
\hline Log likelihood & -3128.56 & - & -2301.92 & - & -1268.96 & - & -679.57 & - \\
\hline
\end{tabular}

* Significant at $1 \%$.

TABle 6: Pooled regression results.

\begin{tabular}{|c|c|c|c|c|}
\hline \multirow{2}{*}{ Variable } & \multicolumn{2}{|c|}{ Incidence of child labour } & \multicolumn{2}{|c|}{ Incidence of dropout } \\
\hline & Coefficient & $z$-statistic & Coefficient & $z$-statistic \\
\hline REG & 0.07 & $2.91^{*}$ & 0.04 & 1.39 \\
\hline SEX & -0.17 & $-8.56^{*}$ & -0.21 & $-9.34^{*}$ \\
\hline $\mathrm{HH}$ & -0.08 & $-21.92^{*}$ & -0.13 & $-28.84^{*}$ \\
\hline MPCE & 0.00 & $-31.85^{*}$ & 0.00 & $-26.65^{*}$ \\
\hline$C_{1}$ & -0.10 & $-3.55^{*}$ & -0.23 & $-7.09^{*}$ \\
\hline$C_{2}$ & -0.41 & $-13.87^{*}$ & -0.43 & $-13.21^{*}$ \\
\hline$C_{3}$ & -0.28 & $-11.76^{*}$ & -0.32 & $-12.24^{*}$ \\
\hline $\mathrm{R}$ & 0.01 & 0.61 & 0.02 & 0.58 \\
\hline FEDU $_{1}$ & -0.44 & $-20.39^{*}$ & -0.32 & $-13.03^{*}$ \\
\hline $\mathrm{FEDU}_{2}$ & -0.81 & $-16.77^{*}$ & -0.65 & $-13.31^{*}$ \\
\hline $\mathrm{MEDU}_{1}$ & -0.45 & $-16.32^{*}$ & -0.32 & $-11.11^{*}$ \\
\hline $\mathrm{MEDU}_{2}$ & -0.84 & $-7.93^{*}$ & -0.55 & $-6.83^{*}$ \\
\hline Number of obsn. & 98568 & - & 98568 & - \\
\hline Sum squared residuals & 1397.723 & - & 2035.426 & - \\
\hline Log likelihood & -7276.151 & - & -9298.472 & - \\
\hline
\end{tabular}

* Significant at $1 \%$.

are significant in most cases. (Only for girl children, scheduled tribe dummy is not significant (both in rural and urban) and religion dummy is not significant only for rural male children.) It indicates the glaring success of minority grouptargeted development policies adopted and implemented at the governmental level in India. So we can be optimistic about the effectiveness of policy recommendations like education for all in reducing incidence of dropout and child labour in India.

The pooled regression outputs are presented in Table 6 . The coefficient of $D_{\text {reg }} 2$ is significant at 1 per cent with positive sign for child labour decision. It implies that children in rural area are more involved in labour type of jobs compared to their counterpart in urban area showing strong regional difference in this respect. In contrast, the coefficient is positive but not significant for dropout decision. Thus, the analysis does not show any significant regional difference in terms of decision of dropout. This might be possible due to Sarva Sikhsha Abhijan, going on extensively all over the country during last ten years. The coefficient of $D_{\text {sex }}$ is negative and highly significant (at 0.01 level) for both incidence of child labour and dropout indicating serious gender implications in these decisions.

\section{Concluding Remarks}

In the present study, household level data of NSS for 61st round (2004-2005) have been used to examine the incidence and pattern of child labour in India across sex and region. The study reveals that the issue of child labour is largely a rural phenomenon and it has significant gender implications. 
This confirms the well-heard criticism of urban bias in all special drives for backward population, providing the advantage to urban centers in terms of infrastructure and manpower, better enforcement, and better monitoring of welfare-policy measures. If the overall prevalence of social justice is to be ensured, special attention should be given to the rural areas with greater participation from local people, potential beneficiaries, and NGOs. The pattern of child employment in various industries reveals the failure of legal steps towards protecting them from occupational hazards.

The determinant analysis shows strong positive effect of parental education as well as income in reducing incidence of child labour and dropout. This suggests the need of a combined measures, improved household prosperity with higher adult education, for a strategy to be effective for the permanent solution of the problem. These must include, for example, continuous effort of adult literacy campaigns like Sarva Siksha Abhijan, that increase social awareness, especially of the adult female as well as employment generation schemes, like National Rural Employment Guarantee Scheme (NREG), that lead to empowering the poor. Moreover, selective policy measures for minority population should be continued to solve the problem permanently.

\section{Appendix}

The list of hazardous industries in Indian context is given in the following:

155: manufacture of beverages;

261: manufacture of glass and glass products;

269: manufacture of nonmetallic mineral products;

281: manufacture of structural metal products, tanks, reservoirs, and steam generators;

289: manufacture of other fabricated metal products; metal working service activities;

291: manufacture of general purpose machinery;

292: manufacture of special purpose machinery;

293: manufacture of domestic appliances;

451: site preparation in construction sector;

452: building of complete construction or parts thereof, civil engineering;

453: building installation;

454: building completion;

455: renting of construction or demolition equipment with operator;

602: other land transport;

603: transport via pipelines;

1511: production, processing and preservation of meat, fish, fruit vegetables, oils, and fats;

1512: processing and preserving of fish and fish products;

1541: manufacture of bakery products;
2011: manufacture of veneer sheets; manufacture of plywood, laminated board, particle board, and other panels and boards;

2022: manufacture of builders' carpentry and joinery.

\section{Acknowledgments}

The author likes to thank D. Mukherjee for his comments at different stages of the work. This paper has also benefited from presentation at 48th Annual Conference of The Indian Econometric Society (TIES).

\section{References}

[1] G. Psacharopoulos, "Child labor versus educational attainment some evidence from Latin America," Journal of Population Economics, vol. 10, no. 4, pp. 377-386, 1997.

[2] P. Jensen and H. S. Nielsen, "Child labour or school attendance? Evidence from Zambia," Journal of Population Economics, vol. 10, no. 4, pp. 407-424, 1997.

[3] R. Ray, "Child labor, child schooling, and their interaction with adult labor: empirical evidence for Peru and Pakistan," World Bank Economic Review, vol. 14, no. 2, pp. 347-367, 2000.

[4] M. Ravallion and Q. Wodon, "Does child labour displace schooling? Evidence on behavioural responses to an enrollment subsidy," The Economic Journal, vol. 110, no. 462, pp. C158-C175, 2000.

[5] S. Das and D. Mukherjee, "Role of women in schooling and child labour decision: the case of urban boys in India," Social Indicators Research, vol. 82, no. 3, pp. 463-486, 2007.

[6] D. Mukherjee and S. Das, "Role of parental education in schooling and child labour decision: urban India in the last decade," Social Indicators Research, vol. 89, no. 2, pp. 305-322, 2008.

[7] TED Case Studies (case no. 510), "Rugmark \& Child Labour, International Service - American University: Washington DC," http://www.american.edu/.

[8] M. Swaminathan, "Economic growth and the persistence of child labor: evidence from an Indian city," World Development, vol. 26, no. 8, pp. 1513-1528, 1998.

[9] K. Basu and P. H. Van, "The economics of child labor," American Economic Review, vol. 88, no. 3, pp. 412-427, 1998.

[10] National Sample Survey Organization, Employment and Unemployment Situation in India, 1999-2000, Ministry of Statistics and Programme Implementation, Govenrment of India, 2006.

[11] International Labour Office, The End of Child Labour: Within Reach, International Labour Office, Geneva, Switzerland, 2006.

[12] UNICEF, "State of the World's Children, 2008: Child SurvivalUnited Nations, New York,” 2008, http://www.unicef.org/ sowc08/docs/sowc08.pdf.

[13] New York State Department of Labor, "Workforce, New York," http://www.labor.state.ny.us/workerprotection/laborstandard s/workprot/stprhboc.htm.

[14] Central Statistical Organisation, "Updated National Industrial Classification-2004 (NIC-2004)," Ministry of Statistics and Programme Implementation, Govt. of India, 2004, http:// mospi.nic.in/mospi_new/upload/nic_2008_17apr09.pdf. 


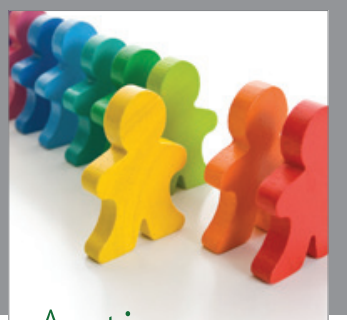

Autism

Research and Treatment
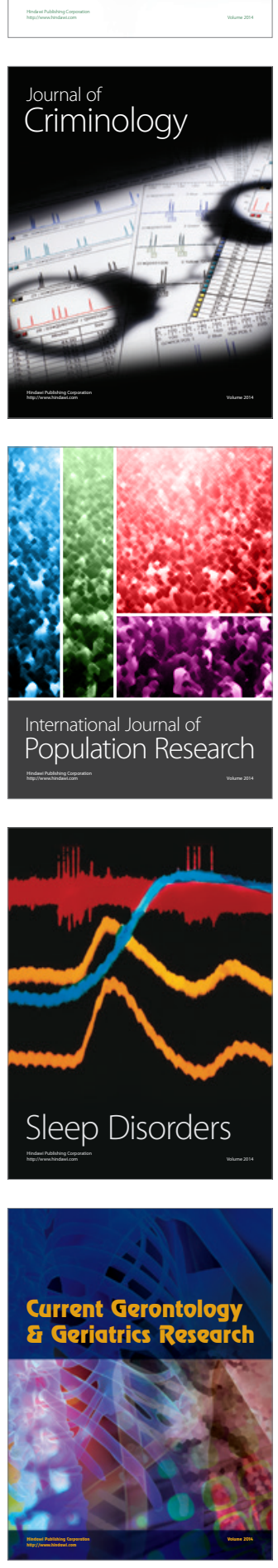
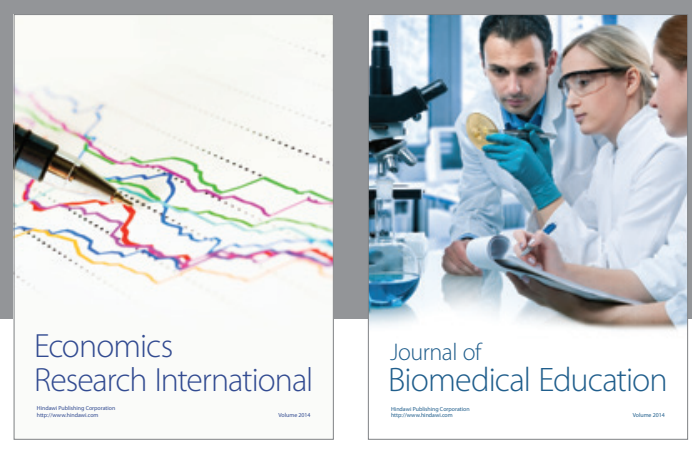

Journal of

Biomedical Education

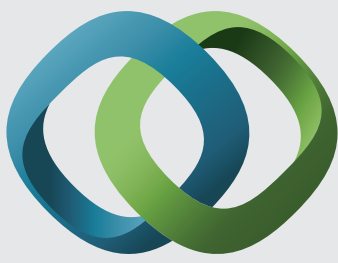

\section{Hindawi}

Submit your manuscripts at

http://www.hindawi.com
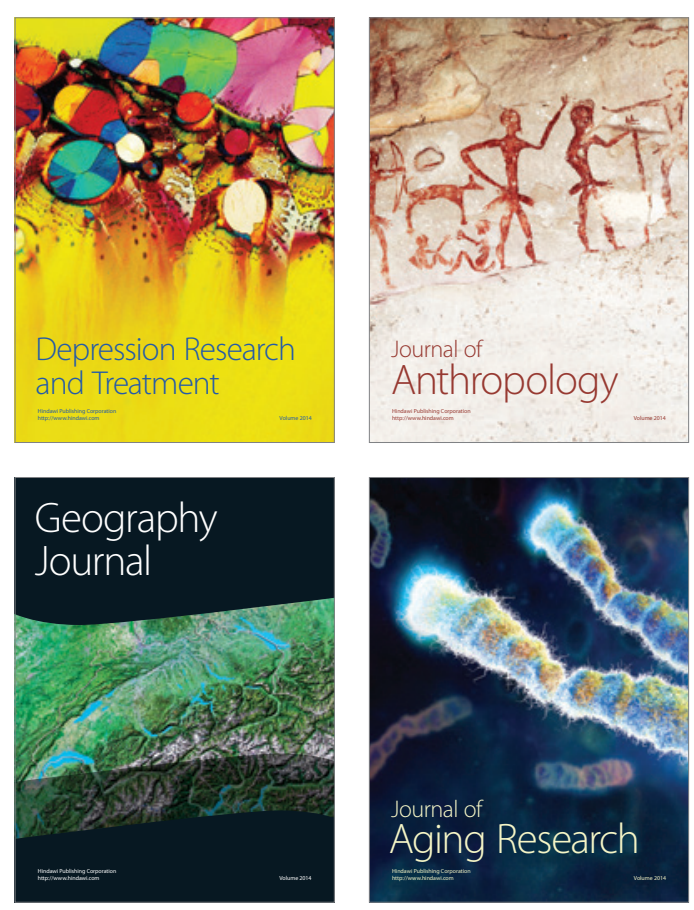

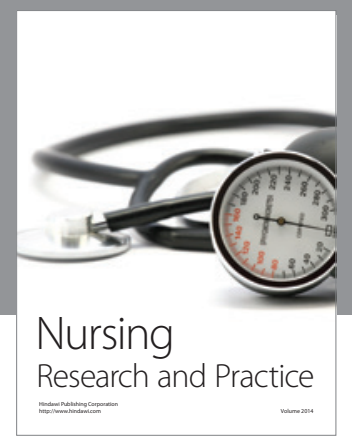

Nursing

Research and Practice

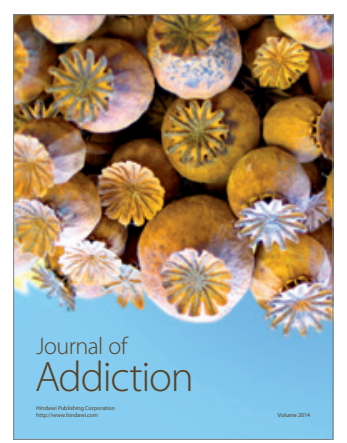

Child Development

Research

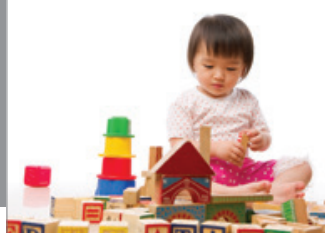

迥
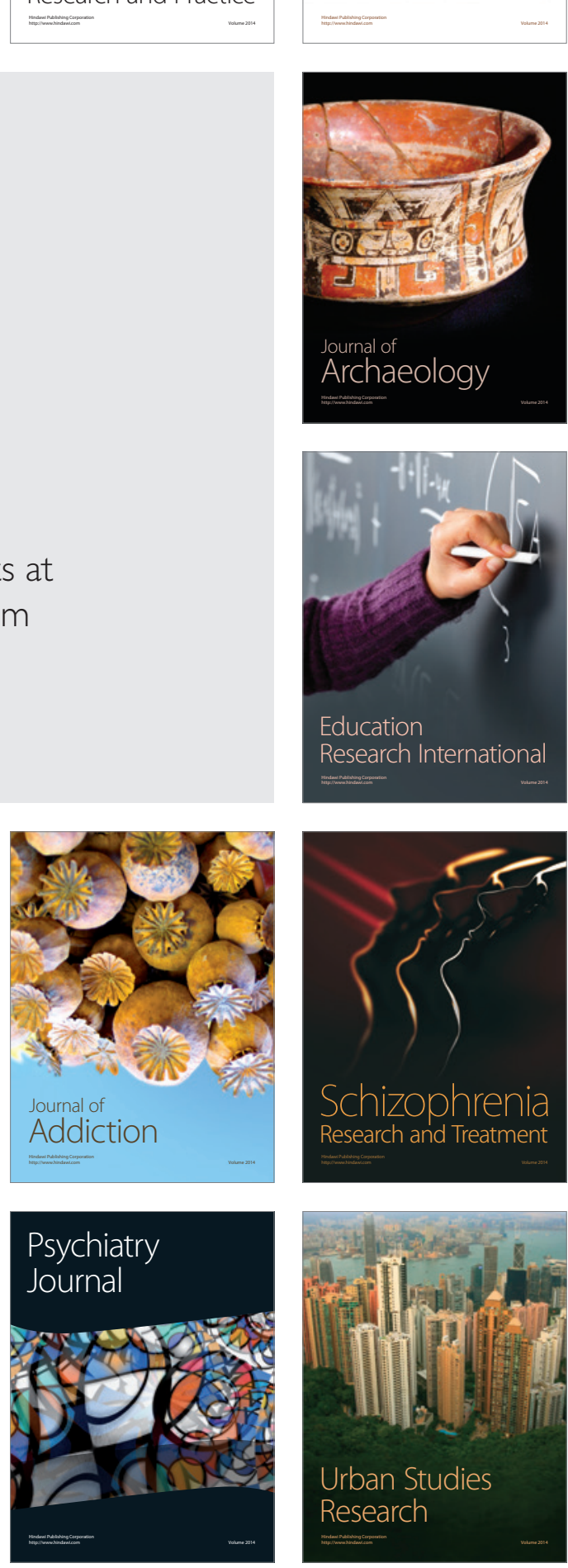